\title{
Religious Minority Sect on Muslim Community In Indonesia
}

\author{
Ramli Abdul Wahid
}

\begin{abstract}
A part of countries that is unreligious state, Indonesia makes Pancasila as the basis of the state, and making it as the base of life in the state and nation. Although Indonesia is unreligious state, the majority of Indonesian embraced Islam, especially the school of Ahlussunnah Waljamaah (Sunni). Among of Sunni communities are affiliated with Al Jam'iyatul Washliyah, Nahdlatul Ulama, Persis, and Muhammadiyah organizations where all Islamic organizations have representatives in Indonesian Ulama Council (MUI). Although dominated by Sunni Muslim societies, the religious sect outside the Sunni or newly religious sect appear from Sunni is also growing in local, national and international scales, such as Shia and Ahmadiyah. Islamic organizations, especially the MUI stated these religious sects as deviant sects. Infrequently the discourse and conflict arose between Sunni and Muslim minority groups. This article examines the existence of religious sect minority in Indonesia, and the MUI's response to various deviant currents. Based on observations and document studies, it is found that many schools and concepts are deviant in Indonesia with a amount of followers, even reappearance responses from the MUI, including Islamic organizations which have spawned religious fatwas related to deviated religious sect and concept in Indonesia.
\end{abstract}

Keywords - Indonesia, fatwa, MUI, cult, Shi'a, Ahmadiyah

\section{INTRODUCTION}

$\mathrm{T}$ HE majority of Muslim in Indonesia has conviction belief to Ahlussunnah Waljamaah, although there is the historian opinion that the Shiites had a role in developing Islam in Indonesian archipelago. Muslim scholars who develop Islam in this area are Sufies which affiliated with the Sunni school, especially Syafi'iyah and Asy'ariyah. Most of the Indonesian Muslim are followers of Nahdlatul Ulama organization, Muhammadiyah, Al Jam'iyatul Washliyah and Persis (The Islamic association). Indonesia is based on Pancasila that ensures freedom in choosing religion and belief, allows various school, belief, and religion which is not formally recognized in Indonesia and can grow and thrive.

Dr. H. Ramli Abdul Wahid, MA, Professor, State Islamic University, North Sumatra, Indonesia.
The existence of religious minority sect grows and develops in the mids of Sunni school which constituted as the majority in Indonesia. According to mass media, the religious sects considered astray area more than 250 sects, and 50 of them developed in Java. Various Islamic organizations such as NU, Muhammadiyah, Al Washliyah, Persis, MUI and muslim scholars individually and collectively have a lot of wasting times to rectify and resolve this issue.

This article will examine the existence of religious minority sects among Sunni majority in Indonesia. In particular, this article examines the religious minority sects which considered deviant in Indonesia, either local scale or national, international, and the response of MUI toward astray sects.

\section{II.MUI AND ASTRAY SECT}

The Indonesian Ulama Council (Majelis Ulama Indonesia/MUI) was established on July 26, 1975 in Jakarta. The establishment of MUI is the result of meeting or deliberation of ulama (muslim scholars), intelectuals, and zu'ama (leaders) in Indonesia. In khitah (core of planning) dedication of the Indonesian Ulama Council is formulated in five functions and main role. They are as the heir of Prophet, as a fatwa giver (mufti), as a counselor and servant of the religious community, agent of reformation movement, and as upholder amar makruf and nahi munkar.

In astray sect context, MUI has published Guidelines to identify sects on November 6, 2007. This document established of 10 criterias of astray sects. First, denying one of the faith pillars and the Islamic pillars. Second, believing or following the creed which is incompatible with syar'i arguments. Third, believing that descend of revelation after the Kur'an. Fourth, denying the authenticity and the truth of the Kur'an. Fifth, doing interpretation of Alquran which is not based on tafsir rules. Sixth, refusing the position of Hadith as a source of Islamic teachings. Seventh, humiliating, harassing and disparaging the prophets and messengers. Eighth, denying the Prophet Muhammad (peace and blessing be upon him) as the last prophet and messenger. Ninth, changing or adding or reducing the principles of worship that have been established by shari'a, such as the pilgrimage not to Baitullah, obligatory prayers are not five times a day. Tenth, assessing other people infidels because of different group without syariah argument .

MUI has issued amount of fatwas for religious sects that considered to be astray in Indonesia. Among them are fatwa for al-Qiyadah al-Islamiyah, fatwa for Ahmadiyah, fatwa for Pluralism, Liberalism and Secularism religion, fatwa for Darul 
Arqam, fatwa for Shi`a, fatwa for Lia Eden. It is undeniable that the MUI fatwas met challenges and criticism from human rights activists and liberal groups in Indonesia. The astray sects can be in local scale, national and international one.

\section{RELIGIOUS MinORITY SECT IN LOCAL SCALE}

Among the astray thoughts is Roy`s concept from Malang, stated that the recitation of prayer must be accompanied with Indonesian translation. He claimed that it was received from God. In Tangerang, the teacher of Nurul Yaqin circle admitted that he met directly with God through ascension. Because of his astray claim, his house was burnt by protesters. In Sulawesi, appeared a man who said recitation of prayers by whistling. Recently, appeared a concept that one who is praying must directly touch the soil of the ground. Others say that prayer is not obligatory in the Kur'an. Prayer is obligated by Imam Syafi'i through the rule in his usul fikih.

In North Sumatra, amount of astray religious sects has grown. Among them is Soul Training, a group that claimed that they have done research. The result of their research showed that the prophet Muhammad did not leave anything except Kur'an. They claimed no tarawih /qiyam al-Lail. This concept is one of Inkar Sunnah.

One of Islamic learning circle in Langkat teaches the changes of recitation of Kur'anic verses. For example, Iyyâka na 'budu wa iyyâka nasta 'în become iyyâka a 'budu wa iyyâka asta'in. Qul huwallâhu ahad become huwallâhu ahad. Because of the strange doctrine and varying the verses of Kur'an, MUI Langkat stated that this concept is an astray concept.

Rudi Chairuddin from Serdang Bedagai district changed the creed to utter "asyhadu an lâ ilâha illallâh wa asyhadu anna Chairuddin rasûlullah". He claimed to be the Prophet of Malayu so, the sacred book of him is in Melayu language.

Shaykh Ahmad Arifin from Medan, North Sumatra claimed himself as Sammaniah tarekat leader. He taught that zakat mal (wealth) should be given to the religious teacher. According to him, mut'ah / Sirri (contract marriage) without her father and a witness is lawful. According to him, the creator of Adam is the angel with the command from God. Because, God may not hold the soil that makes His hands dirty.

\section{The Religious Minority SECt in NATional SCALE}

On national scale, it was found that some of the astray sects that stated by the central MUI among them are Islam Jama'ah, Darul Arqam, Inkar Sunnah, Lia Eden, and alQiyadah al-Islamiyah. The Central MUI states that these sects are very contrary to the Islamic doctrine.
Al-Qiyadah al-Islamiyah sects. This sect is led by Ahmad Mushaddeq who taught the existence of a prophet after the Prophet Muhammad. Ahmad Mushaddeq proclaimed himself to be a prophet on July 23, 2006 in Bogor. For this purpose, syahadah words are changed to, Asyhadu allâ ilâha illallâh wa asyhadu ana Masihal Mau udar rasûlullah. So, the central MUI considered him to be astray ${ }^{2}$.

Due to the state of Al-Qiyadah al-Islamiyah has been decided as astray sect and banned by government, Al-Qiyadah al-Islamiyah later on transformed itself into Fajar Nusantara Movement (Gafatar). The principal of this religious sect is to believe the existence of bearer message from Almighty God, as messiah and savior, that is Ahmad Musadeq named Abdus Salam Messi.

Lia Eden claimed to be in friend with Gabriel and built the Salamullah Religion. Because her claim as being friend of Gabriel, while Gabriel's duty is conveying revelations to the apostles, she was stated by central MUI as astray woman ${ }^{3}$.

The Inkar Sunnah concept rejected the existence of Hadith as a source of Islamic teaching. The Inkar Sunnah group holds the Kur'an only. They do not believe in Hadith, they interpret the Kur'anic verses according to their will. In Jakarta, this group decided to pray five times a day and each prayer consists of two rakats without azan and iqamat ${ }^{4}$.

The thought of Islamic Liberal System (JIL) whose core concepts are that all religions are same, there is no law in Islam, it is only ijtihad (opinion) of scholars, and the Prophet Muhammad is an ordinary man. Religious pluralism views that all religions are equal and all people enter the heaven. Religious secularism is the concept that separates the world's affairs from religion. Religious liberalism claimed that the Kur'an and Hadith passages based on free thought. The three of isms are stated by the Central MUI as the concepts that contradict to Islamic doctrins and prohibited to follow ${ }^{5}$.

\section{V.RELIGIOUS MinORITy SECT IN INTERNATIONAL SCALE}

Several international-scale sects appear in Indonesia. Among them are Ahmadiyah and Shi'a. Both get support from abroad morally and materially, which ultimately makes them grow and develop in Indonesia.

Ahmadiyyah Qadian founded by Mirza Ghulam Ahmad who was born in Qadian, India. He wrote amount of books, among them are al-Istifta ', Maktub Ahmad, Mawahib arRahman. In these books, he confesses to be a Mujaddid, Mahdi, Prophet, and Apostle. He confesses that Gabriel came to him and he received revelation from God. The collection of his revelations is Tazkirah Book which is much thicker than the Kur'an. He confessed that one time he got three hundred thousand miracles and the other time over a million. Among 
these miracles is his claim that whoever hostiles him will be die, he will live over 80 years, he will marry a beautiful woman, Muhammadi Begam, and his versatility to write a book in Arabic while he is not Arab. In reality he died at the age of 70 years, unmarried with Muhammadi Begam, and the people who had been hostiled him do not die.

MUI in the Second of National Congress which took place from 26 May to 1 June 1980 in Jakarta published about Ahmadiyah as sect outside of Islam. This fatwa was reinforced with the Fatwa in seventh of National Congress of MUI on July 28, 2005 in Jakarta that the Ahmadiyyah sect is outside Islam, astray and misleading ${ }^{1}$.

Shi' a Imamiyah which is a Shi'a school that still exists and develops nowadays. The center of Shi a adherants is in the Islamic Republic of Iran, and has many followers in Iraq, Syria and Lebanon. In Indonesia, Shiite Imami followers are increasing but not significant, and spreading in Aceh, North Sumatra, Jakarta, West Java and East Java. Shi'ite adherents in Indonesia build a number of organizations and foundations. Among of its' organizations is the Ikatan Jamaah Ahlul Bait Indonesia (IJABI), the Ahlul Bait Indonesia (ABI), and the Association of Youth Ahlul Bait Indonesia (IPABI). At present, less than 77 Shia foundations in Indonesia are scattered in Aceh, North Sumatra, Palembang, Jakarta, West Java, Central Java, Sulawesi, Kalimantan and East Java. Some publishers in Indonesia publish books that written by Iranian scholars, such as Mizan publisher, Pustaka Hidayah, and Shadra Press. The Islamic Cultural Center in Jakarta is regarded as a Shia carriage in Indonesia. Some Shiite leaders have become politicians; among of them have become legislative members representing nationalist parties ${ }^{2}$.

The Indonesian Ulama Council has recommended the status of the Shi'a school in Indonesia. In the National Working Meeting on Jumadil Akhir 1404 H./Maret 1984 M, the MUI appealed "to the Indonesian Muslims who in Ahlussunnah Waljamaah concept to raise awareness to possibility of inclusion its' concept that based on Shi'a ideology." MUI states that "Shiism as one of the concept which exists in the Islamic world have major differences with the Sunni school of thought (Ahlussunnah Waljamaah) adopted by Indonesian Muslims".

The existence of Shites indeed began to get a reaction from the Sunni community in Indonesia. In Sampang, Madura, the Sunni-Shiite conflict occurred since 2004 that led to violence. The real conflict occurred on Sunday, August 26, 2012 where the Sunni group burned 37 houses of Shiite followers, and physical fights resulting in one death and dozens wounded ${ }^{3}$. This case rose to become a national case. However, similar cases have not occurred in other areas such as Jakarta, West Java, North Sumatra, and Aceh. MUI has also published a book entitled Mengenal dan Mewaspadai Penyimpangan Syiah di Indonesia (Know and Be Careful of Diversity Shi a in Indonesia) written by KH. Ma'ruf Amin, Prof. Yunahar Ilyas, H. Ichwan Sam, and Dr. Ir. Amirsyah. The book is expected to be a guidebook for Muslim community that related to Shiite development in Indonesia.

MUI has prohibited contract marriage which is part of Shi'a school. The MUI ruled that "the mut'ah marriage in unlawful and one who practiced the mut'ah marriage must be brought to the justice in accordance with the prevailing laws and regulations.

\section{CONCLUSION}

It can be concluded that although the majority of Indonesian population embraces Ahlussunnah Waljamaah, it is undeniable that the religious sects that once emerged in the Islamic world grew and developed. Even within the Sunni school community there is a new understanding of religion which is considered by the MUI as a deviant school in Islam. MUI as an Islamic religious institution is supported by Islamic organizations in Indonesia such as NU, Muhammadiyah, Al Jam'iyatul Washliyah and Al-Ittihadiyah. Assessing the growth and development of new concept, schools and understandings in Indonesia, the MUI has addressed and issued fatwas for these new schools and understandings. Among of the religious sect and concepts that get response from MUI are Shi'a, Ahmadiyah, the Community of Islamic Liberal, and a number of small and non-international sects.

\section{REFERENCES}

[1] Ramli Abdul Wahid, Kupas Tuntas Ajaran Ahmadiyah, Medan (2014), pp. 17-18

[2] Sekretariat MUI, Kumpulan Fatwa Majelis Ulama Indonesia, Jakarta (2010), pp.118 -119

[3] Ibid., pp. 61-62

[4] bid., pp. 49-50

[5] Ibid., pp. 96-97

[6] Ibid., pp. 41-42

[7] Mohammad Baharun (Ed.), Mengenal dan Mewasapadai Penyimpangan Syi ah di Indonesia, Jakarta (2013), pp. 62-81

[8] Ibid., pp. 62-65 